\title{
FRONTEIRAS TRANSPLATINAS NOS CONTOS DE SERGIO FARACO
}

\author{
Andrea Cristiane Kahmann* \\ Universidade Federal do Rio Grande do Sul \\ Anselmo Peres Alós* \\ Universidade Federal de Santa Maria
}

\section{Resumo}

Este trabalho aborda a produção literária de Sergio Faraco, adentrando o estudo de fronteiras e de suas implicações nas esferas antropológica, cultural e identitária, valendo-se de ferramentas dos Estudos Culturais e dos Estudos de Tradução.

Palavras-chave: fronteira; tradição; tradução; pampa; influxos literários.

\section{BOUNDARIES TRANSPLATINAS IN SERGIO FARACO'S SHORT STORIES}

\begin{abstract}
This article aims at analyzing Sergio Faraco's short stories when it comes to the implications for the question of anthropologic, cultural and identitary boundaries. For that, we will articulate theoretical tools from Cultural Studies as well as from Translation Studies.
\end{abstract}

Keywords: boundaries; tradition; translation; pampa; literary streams.

O questionamento das tradições na esfera latino-americana teve uma peculiar trajetória na reavaliação das marcas de pertencimento em função de que o fenômeno de consolidação do Estado-nação tipicamente “crioulo" não se encaixava nas teorias europeias sobre nacionalidade. Aos movimentos pela independência político-administrativa que tiveram lugar no século XIX seguiram-se as tentativas de rupturas com um passado comum colonizador e de preenchimento dos vazios deixados pela consciência coletiva amparada em tradições alheias e ilegítimas. Tendo em vista que o latino-americano compõe o Outro do europeu, cabia definir quem seria o Outro do latino-americano. Nesse processo, foi cunhada a alteridade e foram delimitadas as suas fronteiras. Era-se a nação sem sê-la: o nacionalismo incipiente da América Latina era culturalmente colonial e politicamente anticolonial. Nesse contexto paradoxal, insere-se o gaúcho transplatino como objeto de interesse: não se encaixando na sociedade do branco europeizado nem na do índio, ele vacilou entre fronteiras do pertencimento, ou, para empregar o termo de Derrida: oscilou por entrelugares. Conforme Leenhardt (2002, p. 29), as fronteiras induzem a possibilidade de análise sob o paradoxo da ambivalência e da ambiguidade, visto que comportam dois estados de ser ao mesmo tempo em que trazem consigo a possibilidade de ser um outro, um terceiro. Para Pesavento, trata-se de um posicionamento "que envolve o distanciamento e o

\footnotetext{
*Andrea Cristiane Kahmann is a Comparative Literature doctorate student at Universidade Federal do Rio Grande do Sul (UFRGS). E-mail: andreak.ufpb@ gmail.com.

${ }^{* *}$ Anselmo Peres Alós is a Professor at the Department of Letras Vernáculas (DLV) and at the Post-Graduate Program in Letras (PPG-L) at the Federal University of Santa Maria (UFSM), Brazil, and author of A letra, o corpo e o desejo: masculinidades subversivas no romance latino-americano (Florianópolis: Editora Mulheres, 2013). He has obtained his doctoral degree at the Federal University of Rio Grande do Sul (UFRGS). He coordinates the research group Trânsitos teóricos e deslocamentos epistêmicos: feminismos, estudos de gênero e teoria queer (http://dgp.cnpq.br/dgp/espelhogrupo/2712396927889265), and he also participates as researcher at Construções sócio-culturais da Tríplice Fronteira: Brasil - Paraguai - Argentina, (http://dgp.cnpq.br/dgp/espelhogrupo/8444931334508596). E-mail: anselmoperesalos@gmail.com.
} 
estranhamento como atitude, e a ambivalência e a ambiguidade como condição de ser" (P, 2002, p. 38), razão pela qual o fronteiriço é, comumente, referido como excêntrico.

O gaúcho foi consequência de uma zona de conflitos entre três soberanias. Questões comerciais, econômicas, políticas e sociais eram frequentemente resgatadas para insuflar ódio contra o homem do outro lado da fronteira. É inegável que também o pampa se inseriu, conforme perspectiva sociológica sugerida por Martins, ${ }^{1}$ numa situação de fronteira "como lugar social de alteridade, confronto e conflito" (1997, p. 36). Martins refere a fronteira como lugar de morte, não só nas guerras pelo território, mas também às mortes simbólica, cultural e social promovidas pela apropriação e degradação do Outro. Não obstante, a história de lutas entre os atores platinos se esfacela ante a constatação de como "modos de vida e culturas se constroem ou sobrevivem apesar dos recortes que os atravessam, e constituem, à sua maneira, um espaço diferente daquele que tentam definir os Estados, um Estado de cultura mais do que de dispositivos estatais de proteção" (LEENHARDT, 2002, p. 29). E a literatura acompanhou as idas e vindas entre os gaúchos de cada lado da fronteira, consagrando o interstício com suas zonas de contato (conforme CIORANESCU, 1964) e seus influxos.

Afinal, a produção literária do entorno pampiano não passaria incólome pelo fato de compor o único território brasileiro que o colonialismo lusitano conquistou mediante guerras contra outra potência colonial. A proximidade e os contatos do Rio Grande do Sul com o Prata foram, indubitavelmente, refletidos na sua produção escrita. No entanto, o abafar das vozes platinas e a negação dos influxos literários confluíam na tendência da "eliminação do que não é nativo" (SCHWARZ, 2001, p. 113) delineando o que Schwarz designou "nacional por subtração", sem tomar em conta o embuste que se promovia. Foi somente a partir da segunda metade do século XX que se passou a perceber um esforço sistemático de pesquisar e coletar dados que se propusessem a rever textos canônicos, fundadores ou importantes por representarem as transformações sociais que afetaram o cotidiano nesses pagos; com os novos ares provindos da abertura política e do restauro da democracia, coube à crítica reavaliar o legado cultural gaúcho sob um novo viés: o da integração. E, com essas travessias e encruzilhadas, as fronteiras platinas anteciparam um efeito que ficou registrado como típico do sujeito da pós-modernidade: os afetos esmaecidos.

\section{As fronteiras transplatinas e as configurações da dinâmica do sentir}

$\mathrm{Na}$ contingência do percurso histórico, para dar sustentáculo à noção de soberania e proteger o território, formou-se o "Estado-nação", que à estrutura jurídica do Estado Moderno agregou a construção cultural da nacionalidade como uma forma de afiliação “(...) mais complexa que "comunidade", mais simbólica que "sociedade", mais conotativa que "país", menos patriótica que patrie, mais retórica que a razão de Estado (...)" (BHABHA, 1998, p. 199). Seguindo a linha de Bhabha, propõe-se a compreensão da nacionalidade como uma estratégia de identificação cultural e de interpelação discursiva que os Estados operam para legitimar sua atuação e inscrevê-la como fruto de uma vontade coletiva ao mesmo tempo em que transformam o "povo" em sujeito imanente e partícipe das entidades políticas.

Com o escopo de estabelecer ou simbolizar a coesão social, de legitimar instituições, status e relações de autoridade, ou mesmo para inculcar padrões comportamentais foram inventadas as tradições em face do construto de nacionalismo. Hobsbawm e Ranger detiveram-se no estudo das invenções das tradições ${ }^{2}$ e apontaram o surgimento da bandeira, do hino e das armas nacionais com esse pretexto. "Parece que o elemento crucial foi a invenção de sinais de associação a uma agremiação que continham toda uma carga simbólica e emocional, ao invés da criação de estatutos e do estabelecimento de objetivos da associação" (HOBSBAWM e RANGER, 1984, p. 19). Nessa égide, as práticas tradicionais existentes foram revistas, ritualizadas e reinseridas no contexto social com fins a servir aos propósitos nacionais. Canções e danças folclóricas foram imbuídas de conteúdo patriótico-progressista, desenvolveu-se uma série de rituais alicerçados, muitas vezes, na amálgama Estado-Igreja, e impôs-se a criação de um passado antigo que extrapo- 
lasse a continuidade histórica real, fosse pela lenda ou pela invenção. Geraram-se símbolos e imagens oficiais com fins a "personificar" a nação.

A formação de uma cultura nacional, segundo Stuart Hall (2003, p. 48-50) definiu a criação de padrões de alfabetização que generalizavam uma única língua vernácula como meio dominante de comunicação em toda a nação. A fundação de um Estado próprio e o idioma comum são, portanto, elementos de ordem política e cultural de fundamental relevância para o sentimento de solidariedade nacional, visto que o primeiro é condição sine qua non para a existência de uma sociedade política, e o segundo assume dimensões imprescindíveis em face da formação da cultura nacional. As zonas de fronteira, no entanto, apesar de forjadas para a defesa do construto de nação, pendularam entre identidades, podendo, em alguns casos, referirem-se como híbridas. Afinal, segundo a abordagem teórica de Homi K. Bhabha, a constituição dos "entre-lugares" nas articulações de diferenças culturais forneceram subsídios para a "elaboração de estratégias de subjetivação - singular ou coletiva - que dão início a novos signos de identidade e postos inovadores de colaboração e contestação" (BHABHA, 1998, p. 20).

As identidades têm aquilo que Edward Said denomina "geografias imaginárias", com seu senso de lugar, de lar, situado num período determinado, pois "onde, senão na temporalidade, uma identidade se desenvolve?" (SAID, 2003, p. 218). Porém, conforme Hall (2003, p. 70-76), um dos efeitos da globalização foi a separação entre espaço e lugar, sendo que o segundo, nessa égide, deve ser entendido como o ponto de práticas sociais específicas, concreto e delimitado pelo contexto com o qual as identidades estão estreitamente vinculadas. Se na pré-modernidade espaço e lugar eram amplamente coincidentes, paulatinamente eles se foram separando, por meio da inserção de influências sociais distanciadas que moldaram os lugares e deslocaram os seus sujeitos. E esse deslocamento atingiu, também, a noção de tempo. Fredric Jameson, a respeito, comenta: "é possível argumentar, ao menos empiricamente, que nossa vida cotidiana, nossas experiências psíquicas, nossas linguagens culturais são hoje dominadas pelas categorias de espaço e não pelas de tempo, como o eram no perío- do anterior do alto modernismo" (JAMESON, 1997, p. 42). Uma das consequências mais imediatas desse deslocamento foi o descentramento do sujeito (conforme JAMESON, 1997, p. 42), que implicou não apenas algumas rupturas com as tradições, mas o recalque (em acepção freudiana) do sentir. Assim, postula Jameson, o poder oculto da tradição pode ter sido soterrado por autonomia e liberdade, mas "a liberação, na sociedade contemporânea, da antiga anomie do sujeito centrado pode também implicar não apenas a liberação da ansiedade, mas também a liberação de qualquer outro tipo de sentimento, uma vez que não há mais a presença de um ego para encarregar-se de sentir" (JAMESON, 1997, p. 43). O lado sombrio desse fenômeno é assinalado por Giddens como sendo o aumento das dependências e compulsões:

Todo contexto de declínio de tradição oferece a possibilidade de maior liberdade de ação do que antes existia. Estamos falando aqui da emancipação humana dos constrangimentos do passado. A dependência entra em jogo quando a escolha, que deveria ser impelida para a autonomia, é subvertida pela ansiedade. Na tradição, o passado estrutura o presente através de crenças e sentimentos coletivos partilhados. O dependente está igualmente escravizado ao passado - mas porque não consegue escapar do que, originalmente, eram hábitos de estilo de vida livremente escolhidos (GIDDENS, 2005, p. 56-57).

O esmaecimento dos afetos e a ruptura com a tradição abalaram o que se deu a conhecer por "memória" - e, sendo esse um dos pilares constitutivos da estrutura psíquica, alertaram-se os postulados freudianos do "revisitar" o passado para obter maior autonomia para o futuro. A ascensão de novas formas textuais e a especial importância de literaturas comprometidas com o resgate memorialístico implicaram o retorno ao interesse por culturas fronteiriças e por literaturas de áreas culturais da tardia modernidade, como a latino-americana. A luta da cultura contra a uniformidade, nessa égide, veio imbuída do questionamento do próprio ser fronteiriço, ao passo que a América Latina se percebia como estranha em face ao passado indígena e desconfortável ante as nações europeias e suas práticas de expressão 
colonial. A revisão do passado, não só o colonial, mas também em face dos processos ditatoriais e da sucessiva promoção de políticas do esquecimento, originou uma matriz literária essencialmente latino-americana, que restou conhecida como "de testemonio". Ademais, por ser um flagrante e não se prestar a juízos de valores ou a digressões morais, o conto se fixou como gênero capaz de apreender o contexto social estilhaçado ética e ideologicamente, enfocando os afetos esmaecidos sem o compromisso de explicá-los.

Essa é uma característica indelével da obra de Faraco, que narra situações limites, borderlines, fronteiriças sem, no entanto, julgá-las moralmente ou analisá-las mais profundamente. A narrativa curta prestou-se, também, a uma "nova relação com as estruturas de poder" (BITTENCOURT, 1999, p. 60) e, por consequência, com a nação. O personagem fronteiriço, o gaúcho, o castelhano, o representante da ordem brasileira são representados, na escrita de Sergio Faraco, numa estrutura eminentemente pampiana, razão pela qual se pode afirmar que esse escritor traça uma análise da fronteira a partir da mesma fronteira. Ou seja: é como se Faraco elaborasse uma narrativa desde a fronteira, em vez de fazê-lo sobre a fronteira. O entrelugar é, pois, o ponto de onde parte a narrativa e é o ponto de referência daqueles personagens descentrados, que não se sentem sujeitos nem de um lado nem de outro das margens do pertencimento, visto que carregam o ônus de viver o interstício no âmago de sua personalidade e, nesse sentido, antecipam os efeitos sombrios da sociedade globalizada.

\section{Tradição e tradução em Sergio Faraco}

A escrita de Sergio Faraco evoca a fronteira como memória afetiva desse escritor nascido no Alegrete (região fronteiriça do Rio Grande do Sul), e seu trabalho deixa transparecer a preocupação com a desconstrução de mitos e tradições inventadas. Três de suas obras tratam de rever os construtos de nação, pondo em xeque as falácias da História Oficial por meio de intensa pesquisa histórica, cotejando documentos e reconstruindo as provas existentes. Examinando os Autos da Devassa da Inconfidência Mineira, o escritor alegretense ques- tionou a representação do poder na época de Tiradentes. Considerando que esse personagem, até a quarta inquirição, negou a conjuração e, em seguida, sem explicação plausível, assumiu a responsabilidade pelo levante (provavelmente sob tortura e com o claro intento de poupar pessoas influentes), Faraco caminhou na contramão da trajetória do "herói". Opôs-se à história inventada que inspirou a poeta Cecília Meireles, o compositor Fernando Brant, o escritor e jornalista Zuenir Ventura e o cronista e romancista Otto Lara Resende, entre outros tantos que citaram Tiradentes como o emblema da liberdade e da valentia. Mito de origem moderna do ideal de liberdade brasileiro, herói cívico-religioso ${ }^{3}$ que tão conveniente se mostrou aos primeiros republicanos, Tiradentes foi o tema escolhido por Faraco para desmistificar a história da nação e a inércia conservadora da sociedade brasileira.

Convém, entretanto, questionar: que interesse poderia ter esse alegretense, bacharel em Direito, funcionário da Justiça do Trabalho e, sobretudo, contista reconhecido pela abordagem da vida campeira sulina em meter-se na seara dos historiadores e revirar documentos, reconstruir fatos históricos e, inclusive, viajar com a família a Minas Gerais em busca de maiores informações? As respostas para essa questão são vagas e poucas, mas uma coisa é certa: a ânsia por desconstruir mitos, o tom da denúncia, o inconformismo ante a ordem estabelecida e o flerte contínuo com a História são marcas indeléveis de sua produção literária.

Entre os mitos que Faraco se propôs a descontruir está o do próprio gaúcho. Deitando o olhar sobre o homem simples da campanha, o escritor desempenhou papel exponencial na subversão da perspectiva nacionalista do pampa, deixando dialogar as semelhanças e as diferenças entre gaúchos e gauchos não como uma questão de bandeira, mas de tipos humanos. Nutrindose de fontes populares e de experiências temáticas não consagradas, os contos de Faraco subvertem a ótica tradicional do regionalismo:

[...] o regionalismo de Sergio Faraco distingue-se dos demais. Além de representarem uma visão particularizada do homem, que não é tipificado, mas apreendido no que tem 
de mais humano, os seus sentimentos (medo, vergonha, desejo, amor, esperança), seus textos revelam as origens platinas e eruditas e abremse também a outros tipos de literatura "não canonizadas", como a literatura popular, os diários, as correspondências e mesmo àquilo que se convencionou chamar "sub-literatura" (MASINA, 1994, p. 73).

Escapando à idealização e à caricatura, Faraco retomou a figura do gaúcho como homem ou hombre sem desprezar a posição privilegiada que lhe conferiu o estar no entrelugar: nem aqui, nem lá; nem de uma, nem de outra nação; nem da cidade, nem do campo; nem civilização, nem barbárie - e, ao mesmo tempo, tudo junto. Sua narrativa assumiu proporções de êxito justamente por ele ser "um escritor na travessia de culturas" (MASINA, 1994, p. 71), o que explica o interesse por sua obra e a publicação em diversos países, tais como Alemanha, Argentina, Bulgária, Chile, Colômbia, Cuba, Estados Unidos, Paraguai, Uruguai e Venezuela. Ao privilegiar os tipos humanos numa perspectiva pósnacionalista, Faraco foi aclamado pela crítica e resultou merecedor, dentre outros, do Prêmio Nacional de Ficção, atribuído pela Academia Brasileira de Letras à coletânea Dançar tango em Porto Alegre como a melhor obra de ficção publicada no Brasil em 1998.

Mas a influência platina na sua escrita não pode ser justificada tão-somente pelo viver a fronteira; devem ser recordados os quase trinta livros que Faraco traduziu: quase todos do espanhol, e a maioria de escritores platinos. Dentre os vários autores traduzidos por Faraco, um é especialmente mencionado pelo registro de uma amizade iniciada pelas vias dos trâmites autorais: Mario Arregui, cujas obras Cavalos do amanhecer e A cidade silenciosa conformam um interessante trabalho tradutório consignado nas cartas trocadas durante quase quatro anos, até a morte do uruguaio. Dita correspondência, recompilada, transformou-se em publicação em livro pela uruguaia Editora Monte Sexto, em 1990, e a tradução brasileira dessas cartas, sob o título Diálogo sem fronteira, foi publicada pela brasileira L\&PM em 2009. Nessas correspondências, põe-se em evidência o diálogo transfronteiriço em face do literário, deixando transparecer o indivíduo por trás dos papéis de escritor e tradutor, com suas preocupações, suas leituras e suas influências que, certamente, não foram poucas. No interregno em que Faraco e Arregui se corresponderam, o uruguaio preparou Ramos generales, de publicação póstuma, e Faraco escrevia Noite de matar um homem, Doce paraíso e A dama do Bar Nevada, os dois últimos de temática considerada "urbana".

Com efeito, Sergio Faraco, como também Mario Arregui e muitos dos escritores que o alegretense traduziu, é eminentemente um contista. Raras vezes ele se embrenhou por outros gêneros literários. Contudo, uma dessas poucas exceções resultou bastante aplaudida pela crítica e pelo público: Lágrimas na chuva: uma aventura na URSS, compilando memórias sobre a terrível experiência na União Soviética quando, como militante do Partido Comunista, foi estudar em Moscou e, por questionar o regime, acabou sendo compulsoriamente internado numa clínica psiquiátrica. Não surpreende que Faraco tenha levado trinta e cinco anos para conciliar o seu Outro e o seu Eu, partindo não de uma perspectiva historicista, como a que se propunha com Tiradentes, mas flertando, agora, com os assédios da memória. Afinal, a memória é, diferentemente da história, um processo dialógico, ancorando nos traços do passado as imagens que povoam o presente. Pois memória é, ainda, um processo tradutório, visto que “a memória constitui um dispositivo de tradução do passado que justamente trabalha a partir do resto e do trauma” (SELIGMANN-SILVA, 2005. p. 212).

E será possível negar a parcela de responsabilidade que teve, nesse processo de assimilação dos traumas e dos constrangimentos do passado, o trabalho dedicado à lide tradutória? Não há que se perder de vista o duplo movimento travado por todo e qualquer tradutor: a saída de si, do Eu, da cultura originária em direção à apreensão do Outro, do não-eu, assimilando a língua e a cultura alvo (por meio da sua "recriação", como quer Campos), para, enfim, retornar ao Eu. Dessa forma, recordando com Paz que "aprender a hablar es aprender a traducir” (PAZ, 1971, p. 7), inverte-se o predicado para, enfim, lançar uma suspeita: aprender a traduzir é aprender a falar, é aprender/apreender o paradoxo de, a um só tempo, suprimir as diferenças entre culturas e revelá-las mais plenamente. E quem poderá dizer que não foi esse processo de "sair de si mesmo" o que de- 
terminou, em Faraco, a capacidade de falar sobre o seu trauma?

Na esteira do "Faraco-escritor" (em oposição, aqui, ao "Faraco-tradutor"), a ânsia memorialística e o descentramento do sujeito, com sua tentativa desesperada de sobreviver à sociedade do descarte e ao desapego, sempre foram temas constantes de sua narrativa - mesmo antes de Lágrima na chuva. Os críticos costumam apresentar a escrita de Faraco como girando em torno de dois polos principais: os contos de ambientação fronteiriça, a desenvolver-se em torno do universo do gaúcho campeiro ou seus remanescentes, e os de ambientação urbana, pelo qual se movimentam personagens dilacerados pela crueldade da vida social, pela solidão e pelo desejo sexual (GONZAGA, 2004, p. 471). Em um ou em outro polo, contudo, os contos de Faraco se sobressaem por apresentar uma linguagem precisa, na exata medida entre o coloquial e a erudição, e pelo seu estilo ímpar, que faz com que se o considere um escritor de "grande esmero formal e de extraordinária riqueza humana” (GONZAGA, 2004, p. 471).

Contudo, mencionar que o ambiente fronteiriço de Sergio Faraco alimenta-se da "memória do Rio Uruguai e suas margens" (HOHLFELDT, 1981, p. 144) parece não ser suficiente. Deve-se considerar que toda sua narrativa está repleta de um telurismo a realçar "a questão da fronteira como uma espécie de provação, com seus ritos de passagem, ou condenação a um sofrimento sem fim" (MASINA, 2003, p. 49). O personagem pode ser um jovem ou um forasteiro, mas, quase sempre, a trama envolve alguém que está aprendendo a viver na fronteira, com seu olhar de estranhamento ou de ingenuidade em frente às práticas do chibo, dos costumes e dos dramas campeiros. ${ }^{4} \mathrm{O}$ sentimento de estar com um pé do lado de lá e outro do lado de cá é acentuado pelo retrato da fronteira, tão permeável quanto a própria linguagem.

Cabe, ainda, destacar que "muito embora Faraco tenha tido contato com a cultura soviética, armênia, europeia, cuja literatura conhece, será pela vertente da proximidade afetiva - portanto, platina e fronteiriça - que irá conceber parte importante de sua obra ficcional" (MASINA, 1994, p. 72). A fronteira está permanentemente tangendo sua narrativa; não com as glórias de outrora, mas quase como uma sina. Mesmo nas histórias de ambientação urbana, há um ar de solidão, de desconforto e de certa ingenuidade que deixa transparecer um sujeito deslocado, algo que leva a pensar em alguém do interior buscando sobreviver à crueldade da vida nos grandes centros. Ou, talvez, o mais correto fosse advogar no sentido de que, nas obras em pauta, não importa o lugar que ocupa ou a procedência do personagem: tanto na zona urbana quanto na rural as pessoas são acometidas pelo mesmo processo de degradação. Nesse sentido, amplia-se a perspectiva de "fronteira" para além dos aspectos geográficos:

[...] a ideia de fronteira é uma constante e está apresentada tanto em relação ao espaço físico, quanto à perda da inocência ou à própria condição humana. Em qualquer circunstância, ela propicia a vivência de situações-limites - fronteiras, portanto - em que o passado se contrapõe ao presente, os largos espaços de ontem cedem lugar às estreitas habitações, quartos pobres de pensão, cafés, assim como a memória de um tempo que não mais existe contrasta com valores de dignidade cultivados mesmo em contexto adverso. ${ }^{5}$

Em meio a isso tudo, é possível entrever os sintomas característicos das sociedades em vias de fragmentação: os fantasmagóricos constrangimentos do passado; os sentimentos que, importunamente, vêm à tona; o aumento das dependências e das compulsões, principalmente no tocante ao sexo; uma ânsia de se encontrar uma identidade ou algo que, em última análise, concentre valor e permita o ancoramento psíquico. Nesse aspecto, a escolha pelo conto pode ser um indício bastante pertinente de uma tentativa de resgate das tradições, de trazer o sujeito de volta para um universo ficcional vinculado com a terra, com a vertente afetiva e com o compartilhamento de experiências.

\section{$O$ conto e a terra: $O$ resgate do narrador e das tradições do pampa}

Chama a atenção que Faraco, o desbravador de mitos, tenha se decidido pelo conto como gênero preferencial. Afinal, o conto surgiu com o mito; a Bíblia é um livro repleto de contos. Distinguindo-se da saga, po- 
rém, o herói, desde o conto primitivo, requeria ajudas humanas ou mágicas, frequentemente pagãs ou sobrenaturais, mas nunca divinas. E se os personagens não se aventuravam pelas missões destinadas aos escolhidos dos deuses, talvez fosse porque as primeiras formas do conto provieram, justamente, da necessidade de o homem comum verbalizar seus feitos. Daí a tendência à oralidade que resistiu até a narrativa contemporânea e que foi tão elogiada por Benjamin (1993). Em uma escolha que já delata o objetivo de primar pela literatura mais afeita ao tom oral da gauchesca, a preferência de Faraco concorreu para a valoração do narrador, como se fizesse retomar o causo a correr de estância em estância pela peonada para ser contado entre um mate e outro junto ao fogo de chão. Assim, não só a escolha dos temas, mas também a do gênero marca o compromisso dele com a revisão da narrativa pampiana. A propósito, Arregui, que por vezes se embrenhava pela crítica literária, escreveu:

El cuento es viejo como el mundo, como el deseo de los hombres de saber de sí mismos. Se diría que hay en el espíritu humano una eterna, originaria tendencia a narrar cuentos y una congénita disposición para escucharlos. El cuento parece ser hijo del fuego y de la noche. Miles de cuentistas (cuenteros, dicen en otros países de América) fundaron la cuentística: miles de hombres perdidos en la muerte como la lluvia en el mar y que hoy nos es lícito imaginar o soñar como uno solo: un hombre un poco misterioso y de largas barbas blancas que llega sin ser llamado al atardecer [...] que llega y se sienta junto al fuego y narra (ARREGUI, 1985, p. 1).

Esse homem misterioso a narrar seus casos junto ao fogo seria, então, o responsável pela permanência da memória, pela lembrança de feitos e nomes e pelo ancoramento do ouvinte a uma tradição que o acolhe e o faz sentir sujeito: a marca da pertença. E assim a psicologia humana, a lidar com a perspectiva do descarte iminente em face às agruras da pós-modernidade, percebeu-se como integrante de uma história própria $\mathrm{e}$ de uma cultura que a diferencia, marcando-lhe a identidade. Outro aspecto a ser notado é que o conto, antes de tudo, deve ser articulado dentro de limites estabelecidos. O platino Cortázar já tinha dito que "o conto parte da noção de limite" (CORTÁZAR, 1993, p. 52), visto que se realiza quando alcança, no leitor, um efeito que só é possível em função da pouca extensão. É o gênero que prima pelo ponto ótimo da "excitação", angariando a participação efetiva do leitor no texto sem desviar sua atenção. Sobre o tema, em uma carta a Faraco, certa vez, Arregui escreveu:

Los novelistas tienen puerta abierta para contar
pavadas y llenar páginas con cosas obvias, los
poetas tienen permiso para amontonar palabras
descomprometidas e imágenes irresponsables o
intercambiables; los que no podemos joder, los
que sudamos y sufrimos, los "en serio" somos los
cuentistas (ARREGUI; FARACO, 1990, p. 100).

O conto configura um flagrante, um fragmento, a narrativa de uma situação, pouco importando o que vem antes ou depois (SCHNEIDER, 2001). Nesse sentido, para ser eficaz, o bom conto exige a unidade de efeito e a narrativa de um acontecimento de forma tão polida que não venha a ostentar nem uma palavra que não tenha a missão de concorrer para o desfecho. Arregui já dizia que esse é o momento em que os contos "se muerden la cola" (ARREGUI; FARACO, 1990, p. 49), em que atam a narrativa: “ $¿ Q u e ́$ quiero decir cuando hablo de anudar un cuento? Pues lo mismo que cuando se habla de anudar un piolín cuando se ha hecho un paquete. Un cuento con el piolín anudado queda compacto, casi como un proyectil" (ARREGUI; FARACO, 1990, p. 49). A elaboração do conto como "projétil" decorre da tensão que se origina, desde o início, em função da construção condensada. Retomando-se Cortázar, para ele é exatamente na construção condensada do conto que repousa o segredo do bom escritor: na capacidade de prender o leitor e isolá-lo do mundo, conquistando sua cumplicidade a partir de imagens e acontecimentos que, embora limitados, sejam capazes de suscitar uma espécie de abertura que o guie para além do narrado, para essa faixa nebulosa do texto em que algo é dito sem dizê-lo (CORTÁZAR, 1993, p. 52).

Sob essa égide, as ideias de limite/abertura, fragmento/unidade, tensão/cumplicidade, e a possibilidade de pleitear o reconhecimento do leitor por meio de mitos, de imagens, de símbolos, a missão de prender, 
de isolar e, paradoxalmente, de deixar à mostra a brecha e o caminho para ir além aproximam o conto da noção de fronteira. Afinal, o conto é o gênero que, por excelência, comporta a explosão, a ruptura dos limites, a prova de que a realidade é bem mais ampla e dinâmica do que, à primeira vista, pode parecer. Nessa trilha, e retomando Miranda, para quem "fazer uma nação e fazer literatura são processos simultâneos" (MIRANDA, 1994, p. 33), a eleição do conto é uma forma de abrir margem à fronteira e pôr em pauta a ambivalência e a negociação transcultural. É curioso observar que muitos dos grandes contistas foram, exatamente, pessoas a transitar continuamente entre culturas, como Jorge Luis Borges e Julio Cortázar.

Muitos são, portanto, os aspectos a ter em conta diante do contexto em que Faraco e Arregui produziram seus contos e das escolhas que travaram para tanto. Não se pode perder de vista, ainda, a influência que exerceram os ficcionistas do chamado boom latino-americano, que foram lidos e serviram de referência para os escritores. ${ }^{6}$ Todas essas questões ajudam a compor a visão transfronteiriça que eles deixam transparecer em suas literaturas e sobre a qual têm consciência de estarem contribuindo para algo mais. Tanto é que, em 1982, Arregui declarava a Faraco:

Es muy cierto que el público europeo ignoraba la literatura latinoamericana y que ahora ha vuelto sus ojos hacia nuestro continente. Entre otras cosas, ocurre que Latinoamérica (considerada como debe serlo: un único gran país) puede presentar hoy un equipo de escritores (Rulfo, García Márquez, Neruda, Carpentier, Cortázar, Guimarães Rosa, Borges, Onetti y otro muchos) más importante que el de cualquier otro país del mundo. Además, ¿no estará pasando que la literatura latinoamericana detecta de un modo u otro secretos ruidos subterráneos que anuncian terremotos sociales? No olvidemos el brío de la literatura francesa en los años inmediatamente anteriores a 1789 , no olvidemos la erupción de gran literatura en Rusia que se acercaba a 1917 (ARREGUI e FARACO, 1993, p. 80).

O uruguaio parecia ter razão ao mencionar a possibilidade de a literatura detectar "ruídos subterrâneos" e o mesmo pode ser dito quando considerado o sistema platino. A literatura dos gaúchos, que à primeira vista poderia parecer anacrônica em face da queda de tantas e tão grandes barreiras, escondia, nas suas entrelinhas, a missão de construir a nova ordem indissolúvel. No caso gaúcho, mesmo antes da abertura do capital da Netscape, quando nem se ouvia falar em offshoring e a queda do muro de Berlim era mera utopia, o pampa já conformava essa espécie de entrelugar híbrido, antecipando os efeitos e sentimentos que, hoje, se atribuem à globalização. O Rio Grande do Sul ocupava uma posição de estranhamento em frente ao restante do Brasil, mas também em relação às Repúblicas do Prata. Inseria-se, pois, nessa situação de ser borda, margem, franja, estar distante, ser diferente, e, sobretudo, estar relegado à violência simbólica e física.

A condição fronteiriça permeou a cultura gaúcha. E essa referência evoca tanto a cultura em seu sentido amplo, como em termos de cultura artística e letrada. $\mathrm{O}$ homem da campanha, o homem simples, honrado ou desregrado, a conviver com a violência, com as regras próprias da luta pela sobrevivência, foi sempre um relevante tema de expressão artística. É certo que a prerrogativa de conviver com a violência institucionalizada não é um privilégio do gaúcho; menos ainda do fronteiriço. ${ }^{7}$ Não obstante, é inegável que, talvez como em nenhum outro repertório artístico, a violência "meridional", é alardeada com ufania, reafirmando o descrédito pela autoridade e a promoção de meios privados de persecução criminal.

Segundo Masina, "a expressão da crueldade nas literaturas de fronteira decorreu da necessidade de exorcizá-la, nomeando-a e explicitando-a para superar o assombro e o horror que sempre causa" (MASINA, 2003, p. 47). E se as épocas de guerra, com a degola, com a violência sexual, com a castração e com a tomadia institucionalizada, já fazem parte do passado dessas terras, o mesmo não pode ser dito com relação a outras facetas da crueldade. A violência ainda está inserida no cotidiano do homem fronteiriço de várias formas: seja por meio da violência física e de cunho sexual; seja por meio da violência simbólica, a negar-lhe a identificação com o que, de fato, é: um gaúcho/gaucho, um homem rústico, um espoliado, alguém em busca da sobrevi- 
vência e nada mais. Por outro lado, a violência se faz presente, ainda, por meio da negação da infância, do desenvolvimento em condições dignas, a negação do afeto e da paz de espírito. É através dessa faceta que o leitor se solidariza com o personagem dos contos de $\mathrm{Fa}$ raco e Arregui - esses personagens que constroem sua identidade em meio às adversidades da vida ou que são acossados, constantemente, pelas memórias, a entrelaçar o delicado fio do vivido com o do sofrido.

Com efeito, se os filósofos europeus associaram o resgate da memória com a promoção de uma responsabilidade pelo passado, associado ao trauma do holocausto, é possível entrever que o papel desempenhado pelas disputas pelas fronteiras com toda a bagagem de violência que elas retomam exerce uma função muito semelhante à de Auschwitz. E trazer esse passado à tona para ser questionado pelos gaúchos, hoje, é um ato político bastante evidente: é promover a política do não-esquecimento, responsabilizando-se pelo passado e pelo presente de agruras, tão constantes na obra de Faraco. "Dois guaxos" e "Travessia" são dois dos mais sintomáticos contos do escritor alegretense para ilustrar o exposto e desenvolver as noções de fronteira e de memória no seu universo ficcional. ${ }^{8}$

\section{"Dois guaxos": as origens do pampiano errante}

O conto "Dois guaxos" conforma um retrato cru e sofrido do homem fronteiriço em frente a seu destino. A narrativa é em terceira pessoa, sob a ótica de Maninho, um guri de quem não se consegue definir a idade, e que está de partida. Descontente com a vida que levava no rancho onde morava com o pai e a irmã, o menino monta um tordilho e deixa para trás a vida miserável e os personagens de sua miséria. O quadro de violência é logo percebido, pela menção dos maustratos e do descaso paterno. A proximidade do pai com o índio Cacho, as "charlas misteriosas", a canha e o jogo de cartas agravavam a dor da morte da mãe: "o velho nunca prestara e tinha piorado depois da morte da mulher, embebedando-se até em dia de semana e maltratando os filhos por qualquer nonada" (FARACO, 2004, p. 22). Desde o primeiro parágrafo, porém, nota-se que o desalento de Maninho não decorre uni- camente das agressões e bebedeiras do pai. O menino foge, antes de tudo, da imagem do parreiral, com "o pelego branco, Ana, e o bugre naquele assanho de cavalo" (FARACO, 2004, p. 22).

Em "Dois guaxos", como em muitos outros contos de Faraco, é possível perceber, desde o início, uma sucessão de menções que indicam o rumo às questões relevantes da própria condição humana. Os costumes, os afetos e a instituição familiar são postos em destaque e criam no leitor um efeito que se aproxima à piedade pelos personagens e, principalmente, pela sua impossibilidade de transformar a realidade. $O$ fato de o narrador ser uma criança reforça o desalento, como a sugerir que a maldade do mais forte sobre o mais fraco seja parte inevitável da convivência humana. O leitor acompanha o transcurso da narrativa e a transformação do mundo edênico da criança com a sensação de que o desacerto com o mundo não é consequência exclusiva da idade adulta. Já na infância, a angústia e a solidão fazem-se presentes, eventos "que a vida futura só se encarrega de desenvolver e solidificar" (BITTENCOURT, 1999, p. 117). Com efeito, o único relato de carinho a constar no texto é a mais contundente prova de rudeza primitiva: uma troca de carícias incestuosas em uma noite em que a natureza decidira terminar de compor o quadro de dor. Sobre os recuerdos de Maninho com relação à irmã:

Da mana, ai, da mana não sentia raiva alguma, só uma dor no peito, só um caroço na garganta. Já abeirante aos dezessete, morrendo a mãe ela tomara seu lugar, cozinhando, remendando o traperio, ensinando-lhe a ler umas poucas palavrinhas. E até mais do que isso... Viva na sua lembrança estava a noite em que o temporal arrebentara o zinco, destapando metade do ranchinho. Molhada, louca de frio, ela viera se deitar no catre dele. As chicotadas do aguaceiro na parede e aquele vento roncador, os mugidos soluçantes de terneiros extraviados e aquele medo enorme de que o mundo acabasse, e no meio da noite, do vento, da chuva que vinha molhar o xergão com que cobriam os pés, ela quisera que lhe chupasse o seio pequenino. A mornura e o cheiro do corpo dela, e seu próprio coração num galope estreito, uma emoção assim - pensava - não era coisa de se esquecer jamais. Que noite (FARACO, 2004, p. 22)! 
É possível depreender que a abordagem do incesto ajuda a compor, na narrativa, a esteira do "entre": nem tabu, nem perspectivas moralizantes; nem abuso sexual no sentido estrito, nem carícias aceitáveis na ótica da "normalidade". Não tendo mãe nem ninguém que zelasse por ela, em meio à chuva que violentamente lhe destelhara a casa e lhe molhava o catre, Aninha submetia-se à única forma de afeto que podia conhecer. Da mesma forma, para Maninho, o estímulo sexual requerido pela irmã não lhe parecia proibitivo, assumindo, antes, uma conotação de amor, visto que a irmã parecia ser a única pessoa a se preocupar com ele. De fato, o episódio incestuoso vem narrado em uma sequência que conduz à compreensão de que, para o menino, a descoberta da sexualidade, através do pedido de Aninha, impõe-se na mesma ordem lógica das outras atividades em que a menina ocupara o lugar da mãe: cozinhar, remendar, ensinar, dar de mamar. A oferta do peito para consolar o irmão menor em uma noite de chuva foi experimentada não como uma transgressão, mas como um modo de torná-lo "especial". Afinal, eram eles, também, terneiros extraviados a mugir com medo na noite chuvosa. A emoção do momento, porém, desencadeou uma ansiedade que confundiu o guri com relação a seu papel em frente ao objeto do desejo incestuoso. ${ }^{9}$ Essa interpretação é reforçada não só pela linguagem saudosista da narrativa (sem qualquer menção a remorsos e culpas), como também pelos ciúmes que Maninho sentia de Cacho e pela raiva que tinha do pai por este não se importar com a filha.

O acontecido, para Maninho, não tinha qualquer conotação violenta. Violência, nessa égide, seria, antes, o coito (consentido) com o bugre que "desde o primeiro dia, vendo Aninha, não disfarçara suas miradas de cobiça, sua tenção de abuso grosso, e o descaro era tamanho que até se apalpava em presença dela" (FARACO, 2004, p. 23). Assim, imiscuindo-se em seu carinho, aparecia o índio, a quem a mana se entregara. Maninho sofria sua perda, embora soubesse que:

[...] não sendo o bugre, ia ser outro qualquer, algum bombachudo que apeasse por ali e depois se fosse, deixando-a tristonha, solita... solita como se queda uma novilha prenha. E depois, ah, isso já se sabia, depois ia virar puta de rancho, puta de bolicho e no fim uma daquelas reiúnas que vira algumas vezes na carreteira, abanando em desespero para caminhão de gado (FARACO, 2004, p. 23).

O destino da irmã não era bem uma surpresa, mas o ocorrido foi como "um mangaço ao pé do ouvido". Não se animando a matar o índio, Maninho decide, por fim, partir da chacrinha. A sina da irmã era previsível e irreparável, talvez por isso não sentisse raiva. A estreia com o bugre era quase um ritual de passagem para a vida de "puta" que o destino assegurara à menina. Da mesma forma, as carícias solicitadas conformaram, para Maninho, um ritual de passagem para a vida de homem. Embora não tivessem consumado o coito (e, provavelmente, nunca viessem a fazê-lo), Aninha despertou no irmão o desejo de descobrir o mundo. Tanto é que o guri se propõe a partir pensando em conhecer outras mulheres. Aninha, ao oferecer o peito ao irmão, fez desvelar o homem por trás do menino e moldou-lhe a identidade. Não por casualidade, o personagem não tem nome; ele é, simplesmente, o Maninho, ou seja: o caçula que conforma seu "eu" a partir da figura (central) da irmã e, por meio dela, passa a sentir-se identificado.

Com efeito, por trás do sentimento de irmão, está o sentimento de homem e a dificuldade de lidar com o peso de ter sido trocado por outro macho. Não há que se postular perspectivas moralizantes: o que Maninho lamenta não é a perda da "honra familiar", mas o fato de ter sido preterido por Aninha, como se percebe no trecho: "Maninho não conhecia muitas mulheres e nunca dormira com nenhuma, mas com qualquer que pudesse comparar, Aninha parecia mais bonita, bagualazinha jeitosa que dia a dia ia se cascudeando naquelas lidas campeiras" (FARACO, 2004, p. 24). Reforçando essa ideia, a despedida do irmão, enquanto Aninha dormia, não se deu com um beijo no rosto ou na testa, como se poderia supor a princípio. A despedida deu-se com os olhos cheios de lágrimas, quando ele "aproximou o rosto do ventre da irmã. Um beijo, e o sexo dela tinha um cheiro delicado, profundo" (FARACO, 2004, p. 25). Maninho, nessa despedida, arcava, pois, com a grande angústia de nutrir algo mais que um sentimento de irmão sem poder considerarse, de fato, o homem de Aninha. 
O signo do entremeio é ponto a toda hora posto em destaque: nem adultos, nem crianças; nem abandonados, nem criados com zelo; nem proprietários, nem sem-nada; nem analfabetos, nem educados; em algum lugar entre a civilização e a barbárie, os irmãos desse conto estão de tal forma esmaecidos que, da última vez que Maninho vê o pai, a chama do candeeiro "ia mermando, cedendo espaço às sombras" (FARACO, 2004, p. 24), e, ao despedir-se de Aninha, a tênue claridade "fazia do corpo dela um vulto acinzentado" (FARACO, 2004, p. 24), nem invisível, nem nítido.

As regras do jogo ditadas pela sina fronteiriça são vividas com o determinismo de uma tragédia grega. A única salvação possível era a fuga para outro mundo, "más allá das canchas de osso e dos bolichos da Vila do Bororé" (FARACO, 2004, p. 25), que podia incluir, ou não, o cruzamento da fronteira política. Como Édipo desterrado, Maninho parte rumo ao seu próprio destino de adversidades, angústias e incertezas - e esse destino independe da travessia do rio: tanto do lado de lá como no daqui, as agruras seriam as mesmas, ele seguiria sendo um sujeito deslocado, um des-centrado, um fronteiriço.

Um tirão até Itaqui, e depois... quem saberia? Depois ia cruzar o Rio Uruguai, ou não cruzar, ou ia para Uruguaiana, Alegrete, ou para a Barra, Bella Unión, lugares dos quais ouvira um dia alguém falar (FARACO, 2004, p. 25).

Maninho partia com o desejo de "conhecer outras gentes [...], conhecer outras mulheres, mamar noutras tetas" (FARACO, 2004, p. 25) enquanto pensava que, um dia, talvez, até voltasse. Não pela terra, ou pelo pai, nem mesmo pela irmã, mas "voltar para subir o cerrito de pedra nos fundos do campinho, para atirar uma flor na cruz da velha morta, de quem, agora mais do que nunca, sentia tanta saudade" (FARACO, 2004, p. 25). De todas as memórias, a mãe era a única capaz de ancorá-lo. Pilar de um histórico familiar fragmentado após sua morte, esse parecia ser o único condão capaz de ter sustentado alguma forma de honra, o único remédio contra o desabamento das estruturas do sentir. Diante da desgraça da irmã e da decisão de ir embora, Maninho só conseguia pensar "que as mães não deviam morrer tão cedo, na falta delas todo mundo parecia mais solito, espremido no seu cada qual como rato em guampa” (FARACO, 2004, p. 24). A mãe parecia ser o elo de ligação com aquela coisa "que não sabia o que era e já se perguntava, afinal, se não era o tal de amor" (FARACO, 2004, p. 25). Na falta dela, "a família ia bichando, ia ficando podre, ia virando pó" (FARACO, 2004, p. 24). O abalo das estruturas da tradição e o recalque do sentir, nesta narrativa, não decorriam da alteração do entorno cultural ou político. $\mathrm{O}$ espaço e o tempo continuavam sendo percebidos nas mesmas dimensões de outrora. $\mathrm{O}$ soterramento das tradições, aqui, é o que se refere às tradições familiares, sustentadas pela figura materna. $\mathrm{O}$ agravamento dos vícios do pai e o rumo para a perdição da irmã foram consequência desse "desencaixe" provocado pela morte da mãe.

O porquê desse "desencaixe" é desvelado pouco a pouco, enquanto o leitor vai percebendo a profundidade da dor do protagonista. As revelações em série geram uma expectativa que suplanta a tradicional perspectiva de conto com finais inesperados. Desde o início, o leitor é informado que Maninho busca sossego àquele tormento ocasionado pelas lembranças de Ana e do bugre. A irmã que o tinha magoado era, simplesmente, Ana; diferente da mana ou da Aninha que remetia a um passado de recuerdos doces. Porém, o sentido real da oposição entre essas lembranças prazerosas e o tormento do presente e da fuga só ficam claros ao fim da narrativa. $\mathrm{O}$ desvelamento sucessivo foi o recurso do autor para dar conta da intensidade e da brevidade que o conto exige, ao mesmo tempo em que contribuía para o movimento em busca do enigma. Porém, em "Dois guaxos", como em geral o é toda a obra regionalista de Sergio Faraco, a aproximação da narrativa ao caso tem lugar não somente pela escolha do gênero, como também pela linguagem a recriar o registro campeiro, com sua peculiar sintaxe, com silêncios e interjeições próprios. Tal condição permeia não só a reprodução das falas de gente simples por meio do registro letrado, expressa no vocabulário imiscuído de castelhanismos e regionalismos próprios da campanha (charlas, recuerdo, solita, emborrachava, más allá), mas aparece o tempo todo.

Sem dúvida, uma das primeiras coisas a se notar é a força da oralidade que supera, de certa forma, a distância entre o dito e o escrito: "[a] competência para a 
recriação performática talvez seja um dos traços mais característicos da literatura fronteiriça do Brasil e que a aproxima de suas origens ibéricas e, sobretudo, rio-platenses" (MASINA, 2003, p. 45). Nesses termos, é lícito encerrar esta análise afirmando que somente um texto tão repleto de entrelugares deixaria margem a outros espaços possíveis de leitura. As interpretações apresentadas nada mais são do que uma exemplificação da infinidade de leituras possíveis a partir de um texto disposto na "fronteira" entre as linguagens, entre as imagens, entre os afetos, o que ocorre, também, com o conto "Travessia".

\section{"Travessia": o contrabando como prática trans- fronteiriça}

O conto "Travessia" vem narrado em primeira pessoa, a partir da experiência de um menino a acompanhar seu tio na travessia do Rio Uruguai em noite de chuva, com uma chalana carregada de encomendas. Tudo indica que o guri ia pela primeira vez ajudar Tio Joca na prática do chibo, daí o olhar de estranhamento, daí a ingenuidade com que cuidava o lanchão dos fuzileiros. O episódio narrado no conto configura-se, então, como mais um ritual de passagem a que o fronteiriço se submete: a estreia no contrabando de pequeno porte e na luta pela sobrevivência. Não se sabe a idade do guri, mas ele ainda recebia tratamento de criança. Mesmo que os homens tivessem aberto a exceção de dar-lhe um quarto de caneca de vinho, Dona Zaira, a mulher de André Vicente, ainda reconhecia, no guri, o filho que ela não tivera.

André Vicente era o contato do lado argentino, dono de um rancho que ficava "no meio de um matinho, perto do rio" (FARACO, 2004, p. 33). Com a chegada de Tio Joca e do menino, Dona Zaira preparou às pressas um carreteiro de milho verde, e André Vicente abriu um garrafão de um vinho tão gostoso que até o guri ganhou um pouco. Enquanto esperavam a comida, eles bebiam o seu vinho e ouviam Tio Joca, que "como sempre, contou velhas e belas histórias de lutas de chibeiros contra os fuzileiros do Brasil" (FARACO, 2004, p. 33). No ato de contar histórias, o personagem parecia estar percorrendo a mesma senda dos construtos na- cionalistas. Narrando suas lutas, Tio Joca estava legitimando a trajetória dos chibeiros, operando por meio de arranjos literários que definiam um nós heroico contra um Outro errante. Dessa forma, criava estratégias de identificação cultural e reforçava a identidade daqueles homens fronteiriços contra a autoridade estatal. Note-se que, também nas histórias de Tio Joca, havia o confronto direto envolvendo castelhanos e gaúchos-brasileiros. Contudo, na contramão da história oficial, a perspectiva dos chibeiros inovava em função da indiferença quanto aos critérios de nacionalidade. Não há uma fronteira a ser guarnecida, o gaúcho não é um bravo sentinela da nação; ao contrário: é à autoridade estatal que se relega o papel de inimigo, é o representante da nação o homem "do lado de lá". Sul-rio-grandenses e castelhanos estão irmanados no ofício de burlar o construto da nação, preservando a questão humana, a sobrevivência, a gauchidade, o diálogo transfronteiriço.

André Vicente, após o almoço, ajudou Tio Joca a buscar as encomendas: "três ventiladores, uma dúzia de rádios, garrafas, cigarros, vidros de perfume e dezenas de cashemeres" (FARACO, 2004, p. 36). Voltaram ao rancho à noite, em uma carroça com toldo de lona, ajudados por um baixinho que atendia por Carlito. O céu estava carregado e os homens esperavam que chovesse. Provavelmente, acreditavam que, com o mau tempo, os fuzileiros relaxariam na fiscalização. Os chibeiros comemoraram quando começou a repicar a chuva no telhado de zinco, e carregaram a chalana. Embarcaram somente as encomendas, uma pasta velha de colégio a conter comida, Tio Joca, o menino e uma cesta com peixe.

Tio Joca era quem "bracejava com os remos" (FARACO, 2004, p. 34), enfrentando um rio fora do leito, com uma correnteza e uns redemoinhos "daqueles que podem engolir uma chalana com seu remador" (FARACO, 2004, p. 34). Os personagens submetiam-se a muitos perigos: as intempéries do rio, a preocupação com fiscalização dos fuzileiros, a travessia numa madrugada com chuva forte "chicoteando a cara [...] e varando a gola do capote" (FARACO, 2004, p. 35). Se o faziam, é porque estavam precisados: "fim de ano, véspera de Natal, uma boa travessia, naquela altura, ia garantir o sustento até janeiro" (FARACO, 2004, p. 35). O guri ia junto, encarregado de cuidar que a encomenda não 
molhasse e, mais importante: avisar se a luzinha vermelha do "bote dos maricas" se mexesse.

O "bote dos maricas", explica o narrador, era o lanchão dos fuzileiros que fiscalizavam a margem brasileira do Rio Uruguai. O apelido tinha sido dado por Tio Joca, em função do boné com rabinho, usado pela corporação. A luz vermelha do bote piscava sob a névoa que encobria as luzes de Itaqui. Qualquer movimento da luzinha era sinal de perigo para os chibeiros. Afinal, mesmo que parecesse inocente o simples transportar, de lá para cá, algumas mercadorias para serem vendidas, os personagens do conto incidiam na ação típica do Art. 334 do Código Penal: o crime de contrabando ou descaminho. O polo passivo do crime em pauta é a Administração Pública, é o Estado que marginaliza a atividade desses homens que não conheceram os limites políticos e dos quais se exige que reconheçam as incidências tributárias. Obrigados a sobreviver no entrelugar da jurisdição, os personagens representam os excluídos da atividade estatal no tocante ao cumprimento com os deveres da nação. Homens como o Tio Joca são reinseridos no sistema como devedores, invasores, criminosos, mas não como cidadãos.

Se a imagem da travessia induz o leitor ocidental a lembrar de Caronte, o barqueiro das almas, cruzando o rio que separa a vida da morte, as chalanas de Faraco sugerem um ritual menos apocalíptico, embora não menos infeliz. Ir daqui para lá ou de lá para cá dá igual para quem sabe, de antemão, que independentemente de pátria, governo ou autoridade, seguirá à margem. E é por isso que, também para os chibeiros do conto “Travessia”, a definição do Outro não se dá por critérios de nacionalidade. Entre Alvear e Itaqui há mais do que um rio: nota-se uma "zona de confluência" a irmanar os homens sujeitos a esses fluxos de deslocamento para ganhar a vida. E o "inimigo" é, como sempre foi, o representante da autoridade de um Estado conformado em especulações longínquas e indiferentes ao homem fronteiriço, um Estado do qual ele pressente não fazer parte, com o qual não compartilha benesses e por isso, rechaça o seu monitoramento reflexivo. O indivíduo submetido ao entrelugar sofre com a negação de seu rosto e de seu sustento nesses confins empobrecidos pelo descaso dos tomadores de decisão. E é por isso que tanto os homens "de lá" quanto os "de cá" se irmanam em um ofício perigoso, que contraria a lei dos dois países, a fim de obterem o seu sustento. Dessa forma, há o desvelamento de uma questão que se mantinha como uma história cifrada, a rondar sub-repticiamente a trama do conto: não importa que os personagens estejam praticando uma ação prevista no estatuto repressivo, não importa que estejam lesando o Estado na arrecadação de divisas; importa, isto sim, que esses homens têm necessidade de sobreviver à fronteira e o fazem exatamente por meio da fronteira.

Ainda que a prática do chibo parecesse relativamente fácil, em função da familiaridade de Tio Joca com o rio, com o ofício e com a fronteira, ainda que ele fosse treinado a ponto de perceber o motor da lancha enquanto o menino só ouvia os grilos e a rãs, a fronteira configura-se, mais uma vez, como uma sina para os personagens de Faraco. A questão da fronteira como uma espécie de condenação a um sofrimento sem fim é introduzida pela assertiva: "[m]as estava escrito: aquela travessia se complicava”. Ao mencionar que a complicação dos personagens era algo que "estava escrito", o narrador dá uma conotação trágica ao episódio. "Estava escrito" era quase como dizer que não havia escapatória, que o viver na fronteira era arcar com o destino de agruras e desgostos.

A luzinha vermelha do lanchão desapareceu. E não era uma chata passando na frente, não era engano do guri, não era economia de bateria por parte dos fuzileiros. Tio Joca cambou a chalana a favor da corrente$\mathrm{za}$, mudando o ponto de desembarque. Estava atento e "dir-se-ia que, além de ouvir, até cheirava" (FARACO, 2004, p. 36). O menino era incapaz de perceber o perigo, mas Tio Joca, experiente no ofício, mandou meter a encomenda na água. O guri lamentava: "nosso tesouro inteiro mergulhou no rio" (FARACO, 2004, p. 36). Afundava no leito do Uruguai a garantia da sobrevivência até o próximo mês. Pouco depois, um holofote:

\footnotetext{
- Buenas - disse alguém atrás da luz. - Que é que temos por aí?

Sem esperar que mandassem, o tio atirou a ponta do cordame.

- Um rio medonho, doutor tenente.
} 
Um fuzileiro recolheu a corda e prendeu-a no gradeado.

- Que é que temos por aí? - insistiu o tenente.

- Peixe, só uns cascudos para o caldo do guri que vem fome.

- Peixe? Com o rio desse jeito?

- O doutor tenente entende de chibo e de chibeiros, de peixe entendo eu - disse Tio Joca, mostrando a peixalhada no cesto (FARACO, 2004, p. 36).

O tenente ofereceu ajuda para puxar a chalana rio acima, auxiliou o guri quando subia na lancha e passou a mão na sua cabeça: “[t]ão chico e já praticando, hein? Essa é a vida", diz o tenente. O desfecho é duro e com certa dose de comoção, quando o guri observa a reação de Tio Joca, já no alto da lancha, olhando para o rio:

Teso, imóvel, ele olhava para o rio, para a sombra densa do rio, os olhos dele brilhavam na meia-luz da popa e a gente chegava a desconfiar de que ele estava era chorando. Mas não, Tio Joca era um forte. Decerto apenas vigiava, na esteira de borbulhas, o trajeto da chalana vazia (FARACO, 2004, p. 37).

Da leitura do conto, depreende-se que a identificação desse personagem que sobrevive à fronteira ( $\mathrm{e}$ da fronteira) está conformada a partir de um vínculo com o lugar, muito mais do que com o espaço, constituindo um (auto)reconhecimento precário e desvinculado das noções de pátria ou nacionalidade. Irmanados pelo ofício ou por algum outro vínculo que não se consegue identificar, os personagens de "Travessia" são um só grupo social, tanto faz se em uma ou em outra margem do Rio Uruguai. Não é possível sequer lhes definir a nacionalidade. André e Zaira são nomes próprios que podem provir tanto do português quanto do espanhol, e o diminutivo Carlito tampouco causa estranhamento em um contexto em que aparecem construções frasais como: "[a] mulher de André Vicente gostava de me dar confiança porque no tenía hijos" (FARACO, 2004, p. 33). Se eles são argentinos ou brasileiros a morar em Alvear pouco importa, visto que até mesmo os fuzileiros, os representantes da autoridade da nação brasileira, têm sua linguagem influenciada pelos castelhanismos locais: "[b]ueno, venham daí, eu puxo essa chalana rio acima" (FARACO, 2004, p. 37) e "[t]ão chico e já praticando, hein?” (FARACO, 2004, p. 37). Os exemplos da interferência entre os idiomas (grifadas, aqui, em um itálico inexistente no texto original), a ter lugar inclusive entre os representantes do Estado, são relevantes ante a observação que César já tecia a propósito desses pagos em que a marca da cidadania era feita pelo idioma uma vez que, no anonimato do entrelugar pampiano, "a fala materna fazia as vezes de certidão" (CÉSAR, 1978, p. 44). A questão era que até mesmo os fuzileiros sofriam com crise de identidade e a sina da fronteira.

É de notar, ainda, que também essa narrativa transcorre ao arrepio de juízos de valores. Gente simples, em busca de seu sustento, nada mais, os chibeiros têm seus vínculos e suas crenças em uma religiosidade própria: apegam-se a seus santos e, "nos arreglos mais piçudos" (FARACO, 2004, p. 34), quando estes já não resolvem, tratam "direto com o patrão" (FARACO, 2004, p. 34). Não há que se sugerir maldade ou transgressão na prática do contrabando, tal como ela é narrada em "Travessia”. Se houvesse algum mal naquilo que os chibeiros fazem, eles não recorreriam à ajuda divina. Ademais, com o conto, há uma dupla afirmação da atividade do descaminho: a primeira, quando o narrador apresenta a prática do chibo e sugere a continuidade do ciclo; a segunda, quando o escritor insere a questão no âmbito da literatura, perpetuando-a como tema literário.

\section{Notas}

1. José de Souza Martins aborda, no estudo citado, a fronteira com o Outro indígena, no contexto da Amazônia. No entanto, seu trabalho será aqui mencionado no que se aplicar, também, ao entorno pampiano.

2. Os autores detiveram-se nas tradições inventadas tendo por base a realidade inglesa. Para eles, as tradições pertenceriam a três tipos superpostos: (1) as que simbolizam união social, como hinos, bandeiras e armas nacionais; (2) as que legitimam estruturas institucionais, como sistemas legais, aparatos administrativos, educacionais ou religiosos, e (3) as que visam a inculcar sistemas de valores e acordos de conduta, como os costumes. Neste trabalho, serão consideradas, especialmente, as tradições do primeiro tipo, aplicáveis à compreensão do contexto platino.

3. ALKMIN chama a atenção para a conveniência do mito de Tiradentes com relação à construção do ideal 
de homem cristão: "martirizado, figura central de um acontecimento, sua imagem é a construção dos ideais cristãos: humildade, arrependimento e esperança de vida eterna". ALKMIN, Sérgio Vaz. Tiradentes: a origem do mito e o mito de origem. Disponível em: $<$ http://gold.br.inter.net/luisinfo/cidadania/tiradentes. htm>. Acesso em 02 mar. 2006.

4. Gilda Bittencourt observa que Faraco é um escritor que centra boa parte de sua narrativa na infância. Se considerados os contos dos anos 1970, "praticamente metade das histórias relaciona-se com essa fase da vida" (BITTENCOURT, 1999, p. 117). Contudo, mesmo nos contos em que o narrador é adulto, a criança parece vir à tona, resgatando o "eu" passado e narrando seus feitos com as limitações e as lacunas que competem ao olhar ingênuo (Cf. BITTENCOURT, 1999, p. 118).

5. FILIPOUSKI, Ana Mariza Ribeiro. Identidade $e$ construção do imaginário regional em Dançar tango em Porto Alegre. Disponível em: <http://pessoal. portoweb.com.br/sergiofaraco/comentcrit.htm >. Acesso em: 01 jul. 2006.

6. Ademais, suspeita-se que, além do Faraco-escritor, o boom latino-americano tenha sido uma referência para o Faraco-tradutor. Afinal, Sara Viola Rodrigues reitera, citando Heloísa Gonçalves Barbosa, que o chamado boom foi, na realidade, um fenômeno de tradução e recepção da referida literatura no mundo de fala inglesa. Essa perspectiva põe em xeque, portanto, a alardeada teoria que atrela a explosão mencionada como resultado de uma transformação do gênero romance na América Latina, nem consequência do aumento da produção literária de seus escritores (BARBOSA, 1998, p. 173 apud RODRIGUES, 2003, p. 110).

7. Não há estimativa confiável sobre a "taxa de atrito" (que indica a diferença entre crimes cometidos e condenações judiciais consequentes) no Brasil; porém alguns índices apontam para a violência disseminada e institucionalizada. E é notório que a promoção da violência conta com o apoio e a participação da polícia, do Judiciário e outras instituições amparadas pelo Estado. Para ilustrar, dados sobre o segundo trimestre de 1999 no Estado de São Paulo apontam para um total de crimes estimados por pesquisa de vitimização de 1.330.434. No mesmo período, o índice oficial de criminalidade foi de $33 \%$ desse total (443.478 crimes). Em resposta a eles, foram instalados 86.203 inquéritos policiais $(6,4 \%$ do total $)$ e foram efetuadas 29.807 prisões, o que perfaz 2,2\% do total de crimes estimado para o período. Eis o descrédito das autoridades e os meios propícios para a instalação da justiça retributiva privada (ROLIM, 2004, p. 8).
8. As citações referentes aos dois contos de Sergio Faraco serão feitas a partir da seguinte edição: FARACO, Sergio. Contos completos. 2. ed. Porto Alegre: L\&PM, 2004.

9. Como, geralmente, costuma suceder em casos de incesto (MILLER, 1994).

\section{Referências}

ALKMIN, Sérgio Vaz. Tiradentes: a origem do mito e o mito de origem. Disponível em: <http://gold.br.inter. net/luisinfo/cidadania/tiradentes.htm $>$. Acesso em: 02 mar. 2006.

ARREGUI, Mario. Ramos generales. Montevidéu: Arca, 1985.

ARREGUI, Mario; FARACO, Sérgio. Correspondencia: 1981 - 1985. Montevideo: Monte Sexto, 1990.

BARBOSA, Heloísa Gonçalves. Boom or transformation by translation? Transit Circle (Associação Brasileira de Estudos Americanos), Porto Alegre, vol. 1, n. ${ }^{\circ} 1$, p. 173-190, jan. / ago. 1998.

BENJAMIN, Walter. O narrador: observações sobre a obra de Nikolai Leskov. In: VVAA. Benjamin, Horkheimer, Adorno e Habermas - Textos escolhidos. São Paulo: Abril, 1983. p. 63-82.

BHABHA, Homi K. O local da cultura. Tradução Myriam Ávila et al. Belo Horizonte: Editora UFMG, 1998.

BITTENCOURT, Gilda Neves da Silva. O conto sul-riograndense: tradição e modernidade. Porto Alegre: Editora da Universidade (UFRGS), 1999.

CÉSAR, Guilhermino. O contrabando no sul do Brasil. Caxias do Sul: Universidade de Caxias do Sul / Porto Alegre: Escola Superior de Teologia São Lourenço de Brindes, 1978.

CIORANESCU, Alejandro. Princípios de literatura comparada. Tenerife: Universidad de la Laguna, 1964.

CORTÁZAR, Julio. Valise de cronópio. São Paulo: Perspectiva, 1993.

FARACO, Sergio. Contos completos. 2. ed. Porto Alegre: L\&PM, 2004.

FILIPOUSKI, Ana Mariza Ribeiro. Identidade e construção do imaginário regional em Dançar tango em Porto Alegre. Disponível em: $<$ http://pessoal.portoweb.com. $\mathrm{br} / \mathrm{sergiofaraco} / \mathrm{comentcrit.htm}>$. Acesso em: 01 jul. 2006.

GIDDENS, Anthony. Mundo em descontrole: o que a globalização está fazendo de nós. Tradução de Maria Luisa X. de A. Borges. 4. ed. Rio de Janeiro / São Paulo: Editora Record, 2005. 
GONZAGA, Sergius. Curso de literatura brasileira. Porto Alegre: Leitura XXI, 2004.

HABERMAS, Jürgen. Identidades nacionales y postnacionales. Tradução ao espanhol de Manuel Jiménez Redondo. 2. ed. Madri: Tecnos, 1998.

HALL, Stuart. A identidade cultural na pós-modernidade. Tradução de Tomás Tadeu da Silva e Guacira Lopes Louro. 7. ed. Rio de Janeiro: DP\&A Editora, 2003.

HOBSBAWM, E.; RANGER, T. (Orgs.) A invenção das tradições.Tradução de Celina Cavalcante. Rio de Janeiro: Paz e Terra, 1984.

HOHLFELDT, Antonio Carlos. Conto brasileiro contemporâneo. Porto Alegre: Mercado Aberto, 1981.

IZQUIERDO, Iván. Tempo de viver. São Leopoldo: Unisinos, 2002.

JAMESON, Fredric. Pós-modernismo: a lógica cultural do capitalismo tardio. Tradução de Maria Elisa Cevasco. 2. ed. São Paulo: Ática, 1997.

LEENHARDT, Jacques. Fronteiras, fronteiras culturais e globalização. In: MARTINS, Maria Helena (Org.). Fronteiras culturais: Brasil - Uruguai - Argentina. São Paulo: Ateliê Editorial, 2002.

MARTINS, José de Souza. Fronteira: a degradação do Outro nos confins do humano. São Paulo: Hucitec, 1997.

MASINA, Léa. Um escritor na travessia de culturas. In: - Percursos de leitura. Porto Alegre: Instituto Estadual do Livro / Movimento, 1994. p. 71-80.

Tradição, transformação e renovação na literatura sul-rio-grandense de fronteiras. Organon, Porto Alegre, v. 17, p. 45 - 51, dez. 2003.

MILLER, Dusty. Incesto: o centro da escuridão. In: IMBER-BLACK, Evan (Org.). Os segredos na família e na terapia familiar. Porto Alegre: Artes Médicas, 1994. p. 185-199.

MIRANDA, Wander Melo. Nações literárias. Revista Brasileira de Literatura Comparada, São Paulo, n. 02, p. 31-38, mai. 1994.

PAZ, Octavio. Traducción: literatura y literalidad. Barcelona: Tusquets, 1971.

PESAVENTO, Sandra Jatahy. Além das fronteiras. In: MARTINS, Maria Helena (Org.). Fronteiras culturais: Brasil - Uruguai - Argentina. São Paulo: Ateliê Editorial, 2002.

PIGLIA, Ricardo. O laboratório do escritor. São Paulo: Iluminuras, 1994.

RODRIGUES, Sara Viola. Tradução cultural: o que acontece com Um castelo no pampa de L. A. de Assis Brasil. Organon, Porto Alegre, v. 17, p. 109-114, dez. 2003.
ROLIM, M. et. al. Justiça restaurativa: um caminho para os direitos humanos? Porto Alegre: Instituto de Acesso à Justiça, 2004.

SAID, Edward. História, literatura e geografia. In: Reflexões sobre o exílio e outros ensaios. São Paulo: Companhia das Letras, 2003.

SCHNEIDER, Elenor. O conto tradicional e o novo conto na literatura sul-rio-grandense. Signo, Santa Cruz do Sul, v. 26, n. 40, p. 67-101. jan./jun. 2001.

SCHWARZ, Roberto. Nacional por subtração. In: SCHWARZ, Roberto. Cultura e política. São Paulo: Paz e Terra, 2001.

SELIGMANN-SILVA, Márcio. O local da diferença. São Paulo: Editora 34, 2005.

Recebido em: 29/07/2014 Aceito em: 19/09/2014 